\title{
The influence of vaccum pressure on quality and number of recovered oocytes aspirated from ovarian follicles of swine and cows
}

\begin{abstract}
The aim of the present study was stating the influence of the value of vaccum pressure on the percentage of oocytes aspirated from follicles, as well as their quality in heifers, cows, HF, sows and gilts crossbred Landrace. Follicles of $>2 \mathrm{~mm}$ diameter were aspirated. The follicle liquid was obtained with application of the pressure equal to respectively $-150,-100,-70,-50,-30 \mathrm{~mm} \mathrm{Hg}$ respectively. Mean number of recovered oocytes in heifers and cows was respectively 13.3 and 8.4, while sows and gilts 27.5 and 16.3. An average number of the obtained oocytes in heifers and cows reached $61.42 \%$ and $48.9 \%$ and was not dependent on the size of the flow. The vaccum pressure value did significantly influence the number of aspirated oocytes of very good, sufficient and insufficient quality in heifers, as well as oocytes of sufficient and insufficient quality in cows. Alongside with an increase of vaccum pressure above 50 and $70 \mathrm{~mm} \mathrm{Hg}$ in correspondingly heifers and cows, the percentage of insufficient quality oocytes increased while the percentage of very good quality oocytes decreased. An average percentage of recovered oocytes of gilts and sows equalled to 79.1 and $85.2 \%$ and did not depend on the size of the flow. In both gilts and sows the value of the vaccum pressure significantly influenced the number of the recovered oocytes of all classes. Alongside with the growth of the pressure above $50 \mathrm{~mm} \mathrm{Hg}$ the percentage of insufficient quality oocytes increased, while the percentage of very good and good quality oocytes decreased.
\end{abstract}

Key Words: oocyte aspiration, vacuum pressure, sow, cows, in vitro production

\section{Zusammenfassung}

Titel der Arbeit: Einfluss des Vakuumdruckes auf die Qualität und Anzahl abgesaugter Oozyten aus Ovarfollikeln von Kühen und Sauen

Untersucht wurde der Einfluss von Vakuumdruck auf die Anzahl und Qualität abgesaugter Oozyten aus Ovarfollikeln bei Färsen und Kühen sowie Jung- und Altsauen. Die Oozyten wurden von Follikeln $>2 \mathrm{~mm}$ bei Anwendung eines Minusdruckes von -150, -100, -70, -50 und -30 mm Hg gewonnen. Bei Färsen und Kühen wurden 13,3 bzw. 8,4 und bei Jung- bzw. Altsauen 27,7 bzw. 16,3 Oozyten gewonnen. Die Wiederauffindungsrate der Oozyten betrug bei Färsen und Kühen 61,42 \% bzw. 48,9 \% und war unabhängig von der Durchflussgrösse. Die Höhe des Minusdruckes hatte wesentlichen Einfluss auf die Anzahl abgesaugter Oozyten unterschiedlicher Qualitäten. So erhöhte sich bei Färsen und Kühen mit steigendem Minusdruck auf über 50 bzw. 70 mm Hg der Anteil an Oozyten mit mangelhafter Qualität und es sank der Anteil an Oozyten mit guter Qualität. Der durchschnittliche Prozentsatz der wieder aufgefundenen Oozyten bei Jung- bzw. Altsauen betrug 79,1 bzw. 85,2 \% und war ebenfalls unabhängig von der Durchflussgröße. Auch bei den Jung- bzw. Altsauen beeinflusste die Höhe des Minusdruckes die Anzahl und die unterschiedliche Oozytenqualität. Mit dem Druckanstieg >50 mm Hg erhöhten sich die Anteile an Oozyten mit mangelhafter und sanken die mit sehr guten Qualitäten.

Schlüsselwörter: Oozytenabsaugung, Vakuumdruck, Sau, Kuh, in vitro Production

\section{Introduction}

One of the stages of the in vitro embryo production is collecting of immature oocytes from ovarian follicles. A sequence of technical parameters, including the value of vaccum pressure applied during aspiration of ovarian follicles (HASHIMOTO et al., 1998; JAŚKOWSKI, 2001; KRUIP et al., 1994), are mentioned among significant 
elements conditioning both the quality and quantity of cumulus oocyte complex (COC). The data presented so far show that the values of vaccum pressure utilized in collecting of immature oocytes differ from 40 to $400 \mathrm{~mm} \mathrm{Hg}$ (BOLS et al., 1995; BRÜSSOW et al., 1997; SPITSCHAK et al., 1993), in relation to cattle and pigs. Pressure not higher than 100 to $130 \mathrm{~mm} \mathrm{Hg}$ (BRÜSSOW et al., 1994), appears to be optimal for collecting not damaged, high quality oocytes with preserved developmental in vitro culture competence. On the other hand the pressure may have a negative influence on the number of the aspirated oocytes (BOLS et al., 1995).

The aim of the investigation was stating the influence of the vaccum pressure on the number and quality of the post-slaughter oocytes collected from pigs and cows ovaries.

\section{Material and methods}

\section{Ovaries and follicles classes}

The research was carried out on the material obtained from post-slaughter ovaries of gilts and sows as well as heifers and cows. Altogether ovaries were collected from 100 young sows and 44 sows, as well as 21 heifers and 66 cows. According to CAUSHMAN et al. (2000) follicles visible on the surface of ovars depending on their diameter were divided into three classes: small $-<4 \mathrm{~mm}$, medium 4-8 mm and big > $8 \mathrm{~mm}$. In gilts and sows according to RATKY et al. (1995) follicles small, medium and big had diameter 2- > 4, 5-7 and $>7$ mm respectively.

\section{Oocytes aspiration}

The liquid content of ovarian follicles was aspirated with an application of the vaccum aspiratory set V-MAR 5100 (Cook, Australia) designed for Ovum Pick Up (OPU) method. 18G diameter needle was applied to puncture the follicles. The liquid was obtained with the application of the pressure equal to $-150,-100,-70,-50,-30 \mathrm{~mm} \mathrm{Hg}$ respectively, which corresponded to the flow of 133, 110, 85, 71 and $48 \mathrm{ml}$ of water/min respectively. As a recovery rate the number of oocytes obtained from follicles expressed in percentage was claimed.

Evaluation of oocytes

The collected follicle liquid was poured onto scales and after it had been thinned with a small quantity of tissue culture medium (TCM), COCs were selected under a stereoscopic microscope. Immature oocytes were counted and next morphologically evaluated, applying the four- grade scale suggested by DE LOOS et al. (1989). Oocytes of a very high quality (Grade 1) had a compact, multi-layered cumulus with a homogenous plasm thicker than three layers. Oocytes of good quality (Grade 2) had a compact cumulus consisting of one to two layers of cells, with a homogenous ooplasm having a rough and dark transparent layer, oocytes of a sufficient quality (Grade 3) had a less compact cumulus, with an irregular ooplasm, containing dark clusters in ooplasm, as well as oocytes of insufficient quality (Grade 4), depleted of complex cells or an expanding cumulus, irregular ooplasm and jelly-like matrix.

Statistical analysis

The statistical evaluations utilized unidirectional analysis of variance, as well as the procedure of Tukey's multiple comparisons (NIRt) contained in the Analysis Toolpak packet. 


\section{Results}

The number of ovarian follicles from which oocytes were aspirated equaled to 20.9 in heifers compared to 30 found in cows. An average number of aspirated oocytes reached 13.3 in heifers and 8.4 in cows. Altogether 532 follicles were (punctured) aspirated in heifers: 56 (6.5\%)-big ones, 107 (26.3\%)-medium ones and 302 (67.2\%) small ones. The number of ovarian follicles punctured in cows reached 818: 71 (8.7\%)- big ones, 215 (26.3\%)- medium ones and 532 (65\%) -small ones. An average percentage of the recovered oocytes equaled to 61.4 in heifers and 48.9 in cows.

In heifers the value of vaccum pressure significantly influenced the number of obtained oocytes ( $\mathrm{p} \leq 0.001$ and $\mathrm{p} \leq 0.001$ ). In cows the applied vaccum pressure value had no influence on the number of the obtained oocytes (n.s.). The influence of vaccum pressure on recovery rate in heifers and cows shows Table 1.

Table 1

The influence of vaccum pressure on recovery rate in heifers and cows (Einfluss des Vakuumdruckes auf die Qualität abgesaugter Oozyten bei Färsen und Kühen)

\begin{tabular}{llcccc}
\hline \multicolumn{5}{c}{ Pressure value $(\mathrm{mm} \mathrm{Hg})$} \\
\hline & -30 & -50 & -70 & -100 & -150 \\
& $\mathrm{~A}$ & $\mathrm{~B}$ & $\mathrm{C}$ & $\mathrm{D}$ & $\mathrm{E}$ \\
\hline Heifers & & & & & \\
Cows & 83.3 & 81.7 & $47.5^{\text {abd }}$ & 100 & $29.4^{\text {abe }}$ \\
\hline
\end{tabular}

Explanations: A capital letter at a figure stands for a column in which the results differs essentially from the data for $\mathrm{p}<0.01$. . A little letter at a figure stands for the column in which the result differs essentially from the data for $\mathrm{p}<0.05$

The pressure influenced the number of the aspirated (obtained) oocytes of high quality ( $\mathrm{p} \leq 0.001$ ), of sufficient quality ( $\mathrm{p} \leq 0.05)$, as well as of insufficient quality ( $\mathrm{p} \leq$ 0.001), whereas it did not influence the number of oocytes of good quality (n.s.). Detailed data are included in Table 2 which presents the influence of vaccum pressure on the quality of the obtained oocytes in heifers.

Table 2

The influence of vaccum pressure on the quality of the abtained oocytes in heifers (Einfluss des Vakuumdruckes auf die Qualität abgesaugter Oozyten bei Färsen)

\begin{tabular}{cccccc}
\hline \multicolumn{7}{c}{$\begin{array}{c}\text { Pressure value (mm Hg) } \\
\text { Quality of oocytes }\end{array}$} \\
& -30 & -50 & -70 & -100 & -150 \\
& $\mathrm{x}(\%)$ & $\mathrm{x}(\%)$ & $\mathrm{x}(\%)$ & $\mathrm{x}(\%)$ & $\mathrm{X}(\%)$ \\
\hline & $\mathrm{A}$ & $\mathrm{B}$ & $\mathrm{C}$ & $\mathrm{D}$ & $\mathrm{E}$ \\
Grade 1 & $2.6(27.4)$ & $3.5(33.3)^{\mathbf{A C D E}}$ & $1.5(10.4)^{\mathrm{AD}}$ & $2.6(16)$ & $2.0(15)$ \\
Grade 2 & $1.3(13.7)$ & $5.5(33.3)$ & $2.8(19.5)$ & $3.4(20.9)$ & $2.7(20.3)$ \\
Grade 3 & $4.3(45.3)$ & $3.5(21.2)$ & $7.0(49)^{\mathbf{A B D E}}$ & $5.5(33.9)$ & $4.4(33.1)$ \\
Grade 4 & $1.3(13.6)$ & $2.0(12.2)$ & $3.0(21.1)$ & $4.7(29.2)^{\mathbf{B A}}$ & $4.2(31.6)$ \\
\hline Exp
\end{tabular}

Explanations: A capital black letter at a figure stands for a column in which the result differs essentially from the data for $\mathrm{p}<0.01$. A capital letter at a figure stands for the column in which the result differs essentially from the data for $\mathrm{p}<0.05$.

The value of vaccum pressure significantly influenced the number of both sufficient ( $\mathrm{p}$ $\leq 0.05)$ and insufficient ( $\mathrm{p} \leq 0.05$ ) oocytes value, whereas no significant influence of the vaccum pressure value on the number of the obtained oocytes of both very good (n.s.) and good (n.s.) quality was observed. Table 3 presents the influence of vaccum pressure on the quality of the obtained oocytes of cows. 
Table 3

The influence of vaccum pressure on the quality of the aspirated oocytes in cows (Einfluss des Vakuumdruckes auf die Qualität abgesaugter Oozyten bei Kühen)

\begin{tabular}{|c|c|c|c|c|c|}
\hline \multicolumn{6}{|c|}{$\begin{array}{c}\text { Pressure value (mm Hg) } \\
\text { Quality of oocytes }\end{array}$} \\
\hline & $\begin{array}{l}-30 \\
x(\%) \\
\text { A }\end{array}$ & $\begin{array}{l}-50 \\
\times(\%) \\
B\end{array}$ & $\begin{array}{l}-70 \\
x(\%) \\
C\end{array}$ & $\begin{array}{l}-100 \\
x(\%) \\
D\end{array}$ & $\begin{array}{l}-150 \\
\times(\%) \\
E\end{array}$ \\
\hline Grade 1 & 0.7 (33.3) & 4.8 (26.9) & $0.4(25)$ & $0.1(5.4)$ & 0.4 (12.9) \\
\hline Grade 2 & $0.6(28.6)$ & 3.4 (19.1) & $0.8(50)$ & $0.6(31.5)$ & 0.5 (16.1) \\
\hline Grade 3 & 0.3 (14.3) & $7.4(41.5)^{A B B E}$ & 0.3 (18.7) & 0.3 (15.8) & 0.6 (19.3) \\
\hline Grade 4 & $0.5(23.8)$ & $2.2(12.5)^{\mathrm{A} C D E}$ & $0.1(6.3)$ & $0.9(56.2)$ & $1.6(51.7)$ \\
\hline
\end{tabular}

Explanations: A capital letter at a figure stands for the column in which the result differs essentially from the data for $\mathrm{p}<0.05$.

The number of the ovarian follicles from which oocytes were aspirated was in gilts 36 in comparison to 28.8 found in sows. A mean number of oocytes was 27.5 in gilts and 16.3 in swine. The total number of the follicles punctured in gilts was $3604 ; 273$ (7.3\%) were big ones, 834 (23.1\%) medium ones while 2509 (69.6\%) small ones. The number of the punctured ovarian follicles in swine equalled to 1266; 53 (5.9\%) were big ones, 247 (27.0\%)-medium ones and 614 (67.1\%) small ones. An average recovery rate was $79.1 \%$ in gilts and $85.2 \%$ in sows. In gilts and sows the value of vaccum pressure significantly influenced the number of obtained oocytes $(\mathrm{p} \leq 0.001$ and $\mathrm{p} \leq$ 0,001 resp.). The influence of pressure value on recovery rate in gilts and sows shows Table 4.

Table 4

The influence of vaccum pressure value on recovery rate in gilts and sows (Einfluss des Vakuumdruckes auf die Wiederauffindungsrate von Oozyten bei Jung- und Altsauen)

\begin{tabular}{llllll}
\hline \multicolumn{7}{c}{ Pressure value $(\mathrm{mm} \mathrm{Hg})$} \\
& -30 & -50 & -70 & -100 & -150 \\
& $\mathrm{~A}$ & $\mathrm{~B}$ & $\mathrm{C}$ & $\mathrm{D}$ & $\mathrm{E}$ \\
\hline \multirow{3}{*}{ Gilts } & 77.0 & 86.1 & $65.1^{\mathrm{ABDE}}$ & 84.2 & 74.5 \\
Sows & 100 & 84.5 & $20.1^{\text {ABDE }}$ & 95.9 & 76.9 \\
\hline
\end{tabular}

Explanations: A capital black letter at a figure stands for the column in which the result differs essentially from the data for $\mathrm{p}<0.01$.

In gilts the applied pressure significantly influenced $(\mathrm{p} \leq 0.001)$ the number of oocytes of very good $(p \leq 0.001)$, good $p \leq 0.001)$, sufficient $(p \leq 0.001)$ and insufficient $(p \leq$ $0.001)$ quality. Detailed data corresponding to the influence of vaccum pressure on the quality of the aspirated oocytes are presented in Table 5.

Table 5

The influence of vaccum pressure on the quality of oocytes obtained from gilts (Einfluss des Vakuumdruckes auf die Qualität der abgesaugten Oozyten bei Jungsauen)

\begin{tabular}{|c|c|c|c|c|c|}
\hline \multicolumn{6}{|c|}{$\begin{array}{l}\text { Pressure value (mm Hg) } \\
\text { The quality of oocytes }\end{array}$} \\
\hline & $\begin{array}{l}-30 \\
x(\%) \\
\text { A }\end{array}$ & $\begin{array}{l}-50 \\
\times \quad(\%) \\
\text { B }\end{array}$ & $\begin{array}{l}-70 \\
\text { X (\%) } \\
\text { C }\end{array}$ & $\begin{array}{l}-100 \\
x(\%) \\
D \\
\end{array}$ & $\begin{array}{l}-150 \\
x(\%) \\
E \\
\end{array}$ \\
\hline Grade 1 & $1.70(20.8)^{\mathrm{BDE}}$ & 2 (15.6) & $0.33(50)^{\mathrm{AB}}$ & $0.79(9.1)$ & $0.64(5.0)$ \\
\hline Grade 2 & 1.93 (23.6) & 2.28 (31.6) & $1.04(15.9)^{\mathrm{AB}}$ & $1.71(19.6)$ & 1.37 (10.7) \\
\hline Grade 3 & $3.55(43.4)$ & $3.03(42.0)$ & $2.59(39.7)^{\mathrm{EABE}}$ & $1.41(16.1)$ & $3.0(23.4)$ \\
\hline Grade 4 & $1.0(12.2)$ & $0.78(10.8)^{\mathrm{ACDE}}$ & $2.57(39.4)$ & $4.82(55.2)$ & 7.81 (60.9) \\
\hline
\end{tabular}

Explanations: A capital letter at a figure stands for the column in which the result differs essentially from the data for $\mathrm{p}<0.01$ and a capital letter at a figure stands for the column in which the result differs essentially from the data for $\mathrm{p}<0.05$. 
In swine the value of the applied vaccum pressure significantly influenced the number of the aspirated oocytes of very good ( $\mathrm{p} \leq 0.001)$, good $(\mathrm{p} \leq 0.001)$ sufficient $(\mathrm{p} \leq$ $0.001)$ and insufficient $(p \leq 0.001)$ quality. Detailed data related to the influence of vaccum pressure on the quality of obtained oocytes in swine shows Table 6 .

Table 6

The influence of vaccum pressure on the quality of obtained oocytes in swine (Einfluss des Vakuumdruckes auf die Qualität der abgesaugten Oozyten bei Altsauen)

Pressure value (mm Hg)

The quality of oocytes

\begin{tabular}{llllll} 
& -30 & -50 & -70 & -100 & -150 \\
& $\mathrm{x}(\%)$ & $\mathrm{x}(\%)$ & $\mathrm{x}(\%)$ & $\mathrm{x}(\%)$ & $\mathrm{x}(\%)$ \\
& $\mathrm{A}$ & $\mathrm{B}$ & $\mathrm{C}$ & $\mathrm{D}$ & $\mathrm{E}$ \\
\hline & & & & & \\
Grade 1 & $4.07(51.1)^{\mathrm{BCDE}}$ & $1.17(24.4)$ & $0.22(8.5)$ & $0.74(9.4)$ & $0.19(5.4)^{\mathrm{BCD}}$ \\
Grade 2 & $1.48(18.6)^{\mathrm{E}}$ & $1.24(25.8)$ & $0.44(16.5)^{\mathrm{ABD}}$ & $1.52(19.0)$ & $0.30(8.6)^{\mathrm{ABD}}$ \\
Grade 3 & $0.41(5.3)^{\mathrm{ABCD}}$ & $1.72(35.8)^{\mathrm{AE}}$ & $1.0(37.5)^{\mathrm{C}}$ & $1.33(16.7)$ & $0.85(24.4)$ \\
Grade 4 & $2.0(25.1)$ & $0.67(14)^{\mathrm{ACDE}}$ & $1.0(37.5)$ & $4.38(54.9)$ & $2.14(61.6)$ \\
\hline
\end{tabular}

Explanations: A capital black letter at a figure stands for the column in which the result differs essentially from the data for $\mathrm{p}<0.01$. A capital letter at a figure stands for the column in which the result differs essentially from the data for $\mathrm{p}<0.05$.

\section{Discussion}

The value of the applied vaccum pressure during the process of aspiration of oocytes from ovarian follicles remains in a close connection with the percentage of the recovered oocytes and their quality (BOLS et al., 1995; JAŚKOWSKI, 2001; KRUIP et al., 1994; SPITSCHAK et al., 1993; WARD et al., 2000). More oocytes were obtained from cows when applying aspiratory pressure higher than $130 \mathrm{~mm} \mathrm{Hg}$, than when using 50, 70, 90 and $110 \mathrm{~mm} \mathrm{Hg}$ pressure (BOLS et al., 1995). Ward et al. (2000) recorded a linear decrease of the percentage of the obtained oocytes from $69.4 \%$ to $52.2 \%$ in the pressure range between -30 to $-90 \mathrm{~mm} \mathrm{Hg}$. According to their opinion this may be due to the collapse of the follicle around the needle, thus preventing the flow of fluid or trapping of the oocyte. During the collection process oocytes may be damaged by vaccum, velocity, and/or turbulence (HORNE et al., 1996). Attention was also paid to the size of needles (18G, 19G and 21G) applied during aspiration of oocytes (BOLS et al., 1995; HASHIMOTO et al., 1998). KRUIP et al. (1994) maintains that an increase of pressure above $100 \mathrm{~mm} \mathrm{Hg}$ decreases Grade 1 oocytes percentage, as well as an increase of the denuded oocytes (Grade 4) percentage. The exact aspiration vacuum at the tip of the needle depends on the construction of the ovum pick-up device, the length and the diameter of the tubing system, and the diameter of the needle (BOLS et al., 1995; CARTER, 2002).Owing to this fact apart from vacuum pressure expressed in millimeters of mercury, additionally the value of water flow expressed in ml was utilized in our own investigations.

The value of vaccum pressure did not significantly influence the percentage of the recovered oocytes in heifers and cows, while an increase of the percentage of Grade 1 , 3 and 4 oocytes in heifers and Grade 3 and 4 in cows was observed. A significant increase of the percentage of poor quality oocytes was noticeable above $71 \mathrm{ml}$ of water at vaccum pressure. Majority of authors explain the increase by mechanical damages to the oocytes structure occurring as a result of an application of a higher pressure. 
Few works have been devoted to the influence of vaccum pressure applied during aspiration of ovarian follicles in young swine and swine (BRÜSSOW et al., 1994, 1997). According to BRÜSSOW et al. (1997) the percentage of the obtained oocytes stayed at the level of 72.8 to $77.4 \%$ at the values of flow 10 to $47 \mathrm{ml}$ of water/ min (i.e. -30 to $-250 \mathrm{~mm} \mathrm{Hg}$ ). The percentage of the denuded oocytes though was increasing from 2.5 and 1.8 with the flow range of 10 and $32 \mathrm{ml}$ of water/min respectively (respectively 30 and $125 \mathrm{~mm} \mathrm{Hg}$ ) to 9.5 and $16.4 \%$ with the flow range respectively 47 and $66 \mathrm{ml}$ of water/min (respectively 250 and $375 \mathrm{mmHg}$ ). Similarly in our research, a significant increase of the percentage of oocytes of bad and decreasing of the percentage of good and very good quality was connected in the case of young swine and swine with an increase of the value of vaccum pressure above $-50 \mathrm{~mm} \mathrm{Hg}$ (71 $\mathrm{ml}$ of water/min). On the other hand an increase of flow value to $133 \mathrm{ml}$ of water/min did not cause a significant increase of the obtained oocytes.

\section{References}

BOLS, P.E.J.; Van Den HEEDE, J.M.M.; van SOOM, A.; de KRUIF, A.:

Transvaginal ovum pick-up (OPU) in the cow: a new disposable needle guidance system. Theriogenology 43 (1995), 677-687

BOLS, P.E.J.; van SOOM, A.; VANDENHHDE, JM.M.; de KRUIF, A.:

Oocyte pick-up in the cow: The effect of changes aspiration vacuum and disposable needle diameter on the morphology of the cumulus oocyte complex and the developmental capacity of the oocyte. 11'Reunion A.E.T.E.- Hannover, (1995), 132

BRÜSSOW, K.-P.; RATKY. J.:

Repeated laparoscopical follicular puncture and oocyte aspiration in swine. Reprod. Dom. Anim. 29 (1994), 494-502

BRÜSSOW, K.-P.; TORNER, H.; RATKY, J.; HUNTER, M.G.; NÜRNBERG, G.:

Ovum pick up in swine: the influence of aspiration vaccum pressure on oocyte recovery from preovulatory follicles. Acta Vet. Hung. 45 (1997), 189-196

CARTER, J.A.; BELLOW, S.; MEINTJES, M.; PEREZ, O.; FERGUSON B.F.; GODKE, R.A.

Transvaginal ultrasound-guided oocyte aspiration for production of embryos in vitro. Arch. Tierz., Dummerstorf 45 (2002), 99-108

CAUSHMAN, R.A.; HEDGPETH, V.P.; ECHTERNKAMP, S.E.; BRITT, J.H. Evaluation of numbers of microscopic and macroscopic follicles in cattle selected for twining. J. Anim. Sci. 78 (2000), 1564-1567

De LOOS, F.; van VLIET, C.; van MAURIK, P.; KRUIP, T.A.M.: Morphology of immature bovine oocytes. Gamete Res. 24 (1989), 197-204

HASHIMOTO, S.; TAJAJURA, R.; KISI, M.; SUDO, T.; MINAMI, N.; YAMADA, M.: Effects of aspiration vacuum and needle diameter on the recovery rate of bovine cumulus oocytecomplexes by transvaginal aspiration. Theriogenology 49 (1998), 401

HORNE, R.; BISHOP, Ch.J.; REEVES, G.; WOOD, C.; KOVACS, G.T.: Aspiration of oocytes for in-vitro fertilization. Human Reprod. Update 1 (1996), 77-85

JAŚKOWSKI, J.M.: Ovum pick up in cows. Medycyna Wet. 57 (2001), 792 - 795

KRUIP, Th.A.M.; BONI, R.; WURTH, Y.A.; ROELOFSEN, M.W.M.; PIETERSE, M.C.: Potential use ovum pick-up for embryo production and breeding in cattle. Theriogenology 42 (1994), 675-684

RATKY, J.; BRÜSSOW, K.-P.; HUNTER, M.G. Endoscopic studies of ovarian follicle development during the oestrus cycle in Hungarian Large White gilts. Arch. Tierz., Dummerstorf 38 (1995), 427-435

SPITSCHAK, M.; BECKER, F.; KANITZ, W.: Ultrasound-guided investigations of follicular growth and oocyte maturition in cattle. Reprod. Dom. Anim. Suppl. 2 (1993), Abstr. 167 
WARD, F.A.; LONERGAN, P.; ENRICHT, B.P.; BOLAND M.P.:

Factors affecting recovery and quality of oocytes for bovine embryo production in vitro using Ovum Pick-Up technology. Theriogenology, 54 (2000), 433-446

Received: 2006-02-02

Accepted: 2007-02-08

\author{
Author's address \\ Dr. PAWEŁ ANTOSIK \\ Department of Agricultural Veterinary, \\ Faculty of Breeding and Biology of Animals, \\ Agricultural University of Poznań, \\ POZNAŃ, POLAND
}

E-Mail: pantosik@au.poznan.pl 